\title{
Inclusion of NSP-hydrolysing enzymes in diets for broiler chicks containing increasing contents of distillers dried grains with solubles (DDGS)
}

\section{Einsatz von NSP-spaltenden Enzymen in Futterrationen für Broiler mit unterschiedlichen Trockenschlempegehalten (DDGS)}

\author{
Karl Schedle ${ }^{1}$, Elke Humer ${ }^{2}$, Rudolf Leitgeb ${ }^{1}$, Gertrude Freudenberger ${ }^{1}$, Katharina Monika Ebner ${ }^{1}$, \\ Christiane Schwarz ${ }^{1}$
}

\begin{abstract}
${ }^{1}$ Institute of Animal Nutrition, Livestock Products and Nutrition Physiology, Department of Agrobiotechnology, University of Natural Resources and Life Sciences, Vienna (BOKU), Muthgasse 11, 1190 Vienna, Austria

${ }^{2}$ Institute for Animal Nutrition and Functional Botany, Department for Livestock and Public Health in Veterinary Medicine, Veterinary University of Vienna, Veterinärplatz 1, 1210 Vienna, Austria

* Corresponding author: karl.schedle@boku.ac.at
\end{abstract}

Received: 27 July 2016, received in revised form: 11 October 2016, accepted: 21 October 2016

\begin{abstract}
Summary
The objective of the current study was to determine the applicability of wheat-corn-distillers dried grains with solubles (DDGS) as protein source with and without non-starch polysaccharides (NSP)-hydrolyzing enzymes in diets of broiler chicks. In addition to the performance and carcass characteristics, the effect on energy parameters (energy intake per day, energy per kilogram feed), digestibility, as well as sensory aspects and fatty acid profile of breast meat were determined. In a $3 \times 2$-factorial approach, a total of 360 broiler chickens (Ross 308) were allocated to six treatment groups (8\%, 16\%, and 24\% DDGS, with or without NSP-hydrolyzing enzymes). The zootechnical performance was not influenced by increasing DDGS concentrations over the whole fattening period, whereas supplementation of the NSP-hydrolyzing enzyme improved feed conversion ratio in the grower phase and increased average daily gain (ADG) in the finisher phase $(p<0.05)$. Energy and dry matter $(\mathrm{DM})$ digestibility as well as apparent $\mathrm{N}$ retention did not differ between treatments. The substitution of soybean meal and corn with DDGS and vegetable oil showed a trend of increased tenderness of broiler breast meat. Nevertheless, the intramuscular amount of polyunsaturated fatty acids increased with increasing inclusion rate of DDGS and vegetable oil $(p<0.01)$.
\end{abstract}

Keywords: carcass composition, digestibility, fatty acid profile, meat composition, performance

\section{Zusammenfassung}

Ziel der Studie war es, eine Weizen/Mais-Trockenschlempe im Futter für Broiler mit und ohne Nicht-Stärke-Polysaccharid (NSP) spaltendem Enzymzusatz auf die Mast- und Schlachtleistung, Nährstoffverdaulichkeit, Fleischzusammensetzung sowie sensorische Eigenschaften zu testen. Dazu wurden in einem $3 \times 2$ faktoriellen Versuchsdesign 360 Broiler (Ross 308) in sechs Versuchsgruppen ( $8 \%, 16 \%, 24 \%$ Trockenschlempe, jeweils mit und ohne NSP Enzym) aufgeteilt. Eine steigende Konzentration an Trockenschlempe in den Futterrationen für Broiler beeinflusste die zootechnischen Leistungen über die ganze Mastperiode hinweg nicht. Ein Zusatz an NSP-spaltenden Enzymen verbesserte die Futterverwertung in der Mittelmast und die Tageszunahmen in der Endmast $(p<0.05)$. Die Energie- und Trockenmasseverdaulichkeit sowie der N-Ansatz im Körper wurden weder durch Trockenschlempe noch durch den Enzymzusatz beeinflusst. Die Reduktion des Sojaschrot-Maisanteils durch steigende Gehalte an Trockenschlempe und Pflanzenöl resultierte in einem tendenziell zarteren Brustfleisch. Auch der intramuskuläre Anteil an mehrfach ungesättigten Fettsäuren konnte durch einen höheren Anteil an Trockenschlempe und Pflanzenöl in den Broilerrationen erhöht werden $(p<0.01)$. Schlagworte: Schlachtkörperzusammensetzung, Verdaulichkeit, Fettsäuremuster, Fleischzusammensetzung, Leistung 


\section{Introduction}

Producing ethanol from cereals for substitution of motor fuels is widely spread in the world. As a result, the process of cereal-based ethanol production yields a by-product, distillers dried grains with solubles (DDGS), which is available in rapidly increasing quantities as livestock feed. Product variability and lack of information about the nutritional value of DDGS from different sources, as well as the reduced amino acid (AA) digestibility and a AA pattern with low biological value, are reasons for the initial reluctance to use DDGS in diets for pigs and poultry (Nyachoti et al., 2005; Widyaratne and Zijlstra, 2007; Lan et al., 2008; Oryschak et al., 2010). Nevertheless, DDGS yet contains large quantities of nutrients and energy, respectively, including crude protein $(\mathrm{CP})$ and nonphytate phosphorus; hence, it has the potential for being used as livestock feed especially for monogastrics (Nyachoti et al., 2005; Widyaratne and Zijlstra, 2007; Oryschak et al., 2010). An additional feature is the possible partial substitution of soybean meal and corn by DDGS and the regional production. As a result, the consumption of natural feed resources such as grains by pig and poultry feed can be considerably reduced without impairing the animals' health or performance (Schedle, 2016). Above all, monogastric livestock or poultry directly compete with humans for feedstuffs/foodstuffs, because of their similar digestive physiology. Hence, the reduction of cereals in diets for monogastric livestock and poultry is very important from a sustainable point of view (Schedle, 2016).

The DDGS contains high amounts of fiber, mainly consisting of non-starch polysaccharides (NSP). However, composition of NSP can differ considerably in feed stuffs. Different kinds of NSP show various physiological actions in the gut (Montagne et al., 2003). The viscosity-increasing effect of NSP and their negative effects on digestion are well explained in literature (Hansen et al., 1992; Yin et al., 2000; Hogberg and Lindberg, 2004a, b). Supplementation of exogenous NSP-hydrolyzing enzymes to diets rich in NSP (e.g., from fiber-rich by-products such as DDGS) can, therefore, improve digestibility and subsequently the performance of monogastric animals (Emiola et al., 2009; Owusu-Asiedu et al., 2010).

Owing to the high amounts of fiber, the increase in DDGS demands an increase in dietary fat addition in the diet to keep the energy level constant (Thacker and Widyaratne, 2007; Schedle et al., 2010a). As the dietary fatty acid profile has a strong impact on energy, nitrogen, and fatty acid deposition in broiler chickens (Crespo and Esteve-Garcia, 2002), nutrient utilization as well as meat quality may be affected by increasing DDGS contents in broiler diets. In this context, a study was conducted to determine the applicability of a wheat-corn-DDGS as protein source with and without NSP-hydrolyzing enzymes in diets for broiler chicks. Furthermore, effect on energy parameters (energy intake per day, energy per kilogram feed), digestibility of dry matter, apparent $\mathrm{N}$ retention, as well as sensory aspects and fatty acid balance of breast meat were determined.

\section{Material and methods}

\subsection{Animals, housing and diets}

In total, 360 one-day-old Ross 308 chickens were purchased from a commercial hatchery (Helmut Wohlin, Klagenfurt, Austria). Considering initial body weight (BW), one-day-old chicks were distributed equally among 24 pens of $3 \mathrm{~m}^{2}$ and six dietary treatments (four replicates, $15 \mathrm{birds}$ per pen). Animals were housed in the poultry trial station of the institute (Wimitz, Austria). Each of the 24 pens was equipped with wood shavings as litter material, an automatic waterer, infrared warming lamp, and size-adjusted feed troughs. Mash feed and water were offered ad libitum. Nutrient contents of diets met or exceeded the recommendations of the society of nutrition physiology (GfE 1999). The ambient temperature was gradually decreased from $29^{\circ} \mathrm{C}$ at the beginning of the study to $20^{\circ} \mathrm{C}$ at the end of the experiment.

The trial was divided into starter (day 1-14), grower (day 14-28), and finisher (day 28-36) period. Starter (12.4 $\left.\mathrm{AME}_{\mathrm{N}} \mathrm{kg}^{-1} ; 22.0 \% \mathrm{CP}\right)$, grower $\left(12.8 \mathrm{AME}_{\mathrm{N}} \mathrm{kg}^{-1}\right.$; $21.0 \% \mathrm{CP})$, and finisher $\left(12.7 \mathrm{AME}_{\mathrm{N}} \mathrm{kg}^{-1} ; 20.0 \% \mathrm{CP}\right)$ diets were mainly based on corn and soybean meal. Experimental diets (Table 1) were formulated to contain rising amounts of DDGS at the expense of corn and soybean meal. Thus, DDGS originating from wheat and corn was included into the diet at $8 \%, 16 \%$, and $24 \%$ levels. Wheatcorn-DDGS (wheat-to-corn ratio: 44:56) was obtained from an Austrian bioethanol plant (AGRANA, Pischelsdorf, Austria). Analyzed composition of the DDGS (as-fed basis) is given in Table 2. Digestibility values for DDGS were taken from Kluth and Rodehutscord (2010). To improve ethanol extraction, hydrolyzing enzymes of the categories endopeptidases (IUB number 3.4.23.18), cellulases (IUB number 3.2.1.4), $\beta$-glucanases (IUB number 3.2.1.6), $\alpha$-amylases (IUB number 3.2.1.1), and gluco- 
amylases (IUB number 3.2.1.3) were added in the production process of the applied DDGS. Aliquots of the three DDGS basal diets (8\%, 16\%, and 24\% DDGS) were supplemented with an NSP-hydrolyzing enzyme (Roxazyme G2G, DSM Nutritional Products Ltd, Basel, Switzerland) using a dose of $200 \mathrm{ppm}$. The enzyme dose was carefully blended with a portion of the diet before being mixed with the entire feed mix. The NSP-hydrolyzing product is stated by the manufacturer as providing major activities of cellulase, $\beta$-glucanase, and xylanase. NSP-hydrolyzing enzyme was added on top without taking the potential energy contribution into account. Titanium dioxide (0.25\%) was added to all finisher diets as an indigestible marker.

Experimental diets within each growth phase were formulated to contain similar concentrations of total $\mathrm{AME}_{\mathrm{N}}$, digestible (d) lysine (1.16\% starter, $1.05 \%$ grower, and $0.86 \%$ finisher), $\mathrm{d}$ methionine $(0.44 \%$ starter, $0.42 \%$ grower, and $0.37 \%$ finisher), and $\mathrm{d}$ threonine $(0.73 \%$ starter, $0.68 \%$ grower, and $0.62 \%$ finisher). To achieve isocaloric condi- tions, the fat content in the diets was increased linearly with rising DDGS concentration, applying a blend of vegetable oils (Unifrutol’, Garant, Pöchlarn, Austria).

\subsection{Measurements and Chemical Analyses}

Feed samples were obtained from each batch of feed, vacuum packed and stored at $-20{ }^{\circ} \mathrm{C}$ until analysis. All diets were analyzed for dry matter (DM), ash, CP, ether extracts (EE), starch, sugar, neutral detergent fiber (NDF), and acid detergent fiber (ADF) according to standard procedures (Naumann and Bassler, 2012). AA composition was analyzed by applying the methods of Altmann (1992). P was determined photometrically (U5100-SpectrophotometerHitatchi, Metrohm, Vienna, Austria) using the vanadomolybdate method to measure color intensity at $436 \mathrm{~nm}$ after wet ashing of feed samples in $\mathrm{HNO}_{3}$ and $\mathrm{H}_{2} \mathrm{O}_{2}$ via microwave (MLS-ETHOS plus Terminal 320, Leutkirch, Germany). $\mathrm{Ca}$ and $\mathrm{Na}$ were determined by flame atomic

Table 1. Composition (\%) of the experimental diets

Tabelle 1. Zusammensetzung (\%) der Versuchsfuttermischungen

\begin{tabular}{|c|c|c|c|c|c|c|c|c|c|}
\hline \multirow[b]{2}{*}{$\%$ DDGS } & \multicolumn{3}{|c|}{ Starter diet } & \multicolumn{3}{|c|}{ Grower diet } & \multicolumn{3}{|c|}{ Finisher diet } \\
\hline & 8 & 16 & 24 & 8 & 16 & 24 & 8 & 16 & 24 \\
\hline \multicolumn{10}{|l|}{ Feed components, $\%$} \\
\hline Wheat-corn-DDGS & 8.00 & 16.00 & 24.00 & 8.00 & 16.00 & 24.00 & 8.00 & 16.00 & 24.00 \\
\hline Soybean meal & 33.41 & 28.50 & 23.60 & 31.04 & 26.13 & 21.23 & 23.74 & 18.84 & 13.93 \\
\hline Corn & 50.29 & 46.53 & 42.77 & 51.41 & 47.65 & 43.88 & 57.99 & 54.27 & 50.53 \\
\hline Corn gluten & - & - & - & - & - & - & 3.00 & 3.00 & 3.00 \\
\hline Vegetable oil ${ }^{1}$ & 5.05 & 5.67 & 6.29 & 6.48 & 7.10 & 7.71 & 4.60 & 5.22 & 5.84 \\
\hline Feed lime & 1.288 & 1.411 & 1.534 & 1.134 & 1.257 & 1.381 & 1.184 & 1.307 & 1.431 \\
\hline Dicalcium phosphate & 1.137 & 0.969 & 0.801 & 1.207 & 1.038 & 0.870 & 0.991 & 0.822 & 0.654 \\
\hline Salt & 0.226 & 0.180 & 0.134 & 0.277 & 0.182 & 0.136 & 0.230 & 0.184 & 0.138 \\
\hline Vitamin premix ${ }^{2}$ & 0.030 & 0.030 & 0.030 & 0.030 & 0.030 & 0.030 & 0.030 & 0.030 & 0.030 \\
\hline Trace element premix ${ }^{3}$ & 0.056 & 0.056 & 0.056 & 0.056 & 0.056 & 0.056 & 0.056 & 0.056 & 0.056 \\
\hline L-lysine & 0.203 & 0.311 & 0.418 & 0.137 & 0.245 & 0.352 & 0.040 & 0.147 & 0.254 \\
\hline DL-methionine & 0.145 & 0.145 & 0.144 & 0.136 & 0.136 & 0.135 & 0.072 & 0.071 & 0.070 \\
\hline L-threonine & 0.020 & 0.049 & 0.078 & 0.049 & 0.034 & 0.063 & 0.000 & 0.000 & 0.016 \\
\hline Cholin-Cl & 0.080 & 0.080 & 0.080 & 0.080 & 0.080 & 0.080 & 0.040 & 0.040 & 0.040 \\
\hline Elancoban & 0.050 & 0.050 & 0.050 & 0.050 & 0.050 & 0.050 & - & - & - \\
\hline Loxidan & 0.010 & 0.010 & 0.010 & 0.010 & 0.010 & 0.010 & 0.010 & 0.010 & 0.010 \\
\hline ZY-Phytase & 0.010 & 0.010 & 0.010 & 0.010 & 0.010 & 0.010 & 0.010 & 0.010 & 0.010 \\
\hline Titanium dioxide & - & - & - & - & - & - & 0.25 & 0.25 & 0.25 \\
\hline
\end{tabular}

${ }^{1}$ Unifrutol $^{\oplus}$, Garant, Pöchlarn, Austria

${ }^{2}$ One kilogram of vitamin premix includes 40,000,000 IU vitamin A, 16,500,000 IU vitamin D, 165,000 mg vitamin E, 13,500 mg vitamin K, 10,000 mg vitamin B1, 25,000 mg vitamin B2, 15,000 mg vitamin B6, $75 \mathrm{mg}$ vitamin B12, 230,000 mg nicotinic acid, 65,000 mg pantothenic acid, 6,500 mg folic acid, $400 \mathrm{mg}$ biotin ${ }^{3}$ One kilogram of trace element premix includes $120 \mathrm{~g} \mathrm{Fe}, 120 \mathrm{~g} \mathrm{Zn}, 180 \mathrm{~g} \mathrm{Mn}, 30 \mathrm{~g} \mathrm{Co,} 2 \mathrm{~g} \mathrm{I}, 2 \mathrm{~g} \mathrm{Co,} 0.8 \mathrm{~g} \mathrm{Se}$ 
absorption spectrophotometry (AAnalyst 200, Perkin Elmer, Brunn am Gebirge, Austria). The concentration of $\mathrm{TiO}_{2}$ was determined photometrically following sulfuric acid digestion, as described by Jagger et al. (1992). An adiabatic oxygen bomb calorimeter (IKA-C400, Staufen, Germany) was used to determine the gross energy (GE). Broiler chickens' BW and feed consumption were evaluated per pen on days $1,14,28$, and 36 . Average daily gain (ADG), average daily feed intake (ADFI), and feed conversion ratio (FCR) were calculated for the starter, grower, finisher, and the whole fattening period.

On days 32 and 33 of fattening, clean excreta (free from feathers and feed) were collected twice daily from steel liners placed in the collection trays underneath each pen of birds. The excreta from the four collections from each cage were pooled and then frozen for storage. Nitrogen and DM content (Naumann and Bassler, 2012) was determined in thawed digesta. Before the analysis of GE (Naumann and
Bassler, 2012) and $\mathrm{TiO}_{2}$ (Jagger et al., 1992), the samples were freeze dried (TELSTAR LyoBeta 15, Terrassa, Spain), followed by grinding.

After analysis, the energy lost in excreta was determined and the $\mathrm{AME}_{\mathrm{N}}$ was calculated as follows: $\mathrm{AME}_{\mathrm{N}}\left(\mathrm{kJ} \mathrm{kg}^{-1}\right.$ of diet $)$ $=\mathrm{GE}_{\text {diet }}-\left[\mathrm{GE}_{\text {excreta }} \times\left(\right.\right.$ marker $_{\text {diet }} /$ marker $\left._{\text {excreta }}\right)-34.42 \times\left(\mathrm{N}_{\text {diet }}\right.$ $-\mathrm{N}_{\text {excreta }} \times\left(\right.$ marker $_{\text {dier }} /$ marker $\left.\left.\left._{\text {excreta }}\right)\right)\right]$ where GE is the gross energy $\left[\mathrm{kJ} \mathrm{kg}^{-1}\right.$ of sample (diet, excreta)] and marker is the concentration of $\mathrm{TiO}_{2}$ (Hill and Anderson, 1958; GfE, 1999).

At the end of the experiment, broilers were stunned and killed by bleeding in the slaughter house of the poultry trial station. At the day of slaughter and the subsequent day, dressing, eviscerated carcass (weight of the slaughtered animals without blood, feathers, uropygial gland, viscera, abdominal fat, and giblets), chilled carcass (weight of eviscerated carcass after 16-h storage in a cooling chamber at $+3{ }^{\circ} \mathrm{C}$ ), carcass for grilling (weight of chilled carcass without head and neck and legs at the hock joints), and

Table 2. Analyzed nutrient and amino acid content of the experimental diets and DDGS (in $\mathrm{g} \mathrm{kg}^{-1}$ as fed)

Tabelle 2. Analysierte Nährstoff- und Aminosäurengehalte der Versuchsfuttermischungen sowie der Trockenschlempe (DDGS) (in g kg ${ }^{-1}$ Frischmasse)

\begin{tabular}{|c|c|c|c|c|c|c|c|c|c|c|}
\hline \multirow[b]{2}{*}{$\%$ DDGS } & \multicolumn{3}{|c|}{ Starter diet } & \multicolumn{3}{|c|}{ Grower diet } & \multicolumn{3}{|c|}{ Finisher diet } & \multirow[t]{2}{*}{ DDGS } \\
\hline & 8 & 16 & 24 & 8 & 16 & 24 & 8 & 16 & 24 & \\
\hline $\mathrm{DM}$ & 908 & 914 & 907 & 899 & 898 & 900 & 895 & 896 & 906 & 926 \\
\hline $\mathrm{AME}_{\mathrm{N}}, \mathrm{MJ} \mathrm{kg}^{-1 *}$ & 12.8 & 12.7 & 12.6 & 13.3 & 13.2 & 12.9 & 13.0 & 12.9 & 12.8 & 8.8 \\
\hline $\mathrm{CP}$ & 235 & 234 & 230 & 215 & 217 & 216 & 201 & 202 & 206 & 322 \\
\hline $\mathrm{EE}$ & 75 & 83 & 95 & 90 & 99 & 105 & 77 & 85 & 95 & 90 \\
\hline Ash & 53 & 53 & 55 & 53 & 52 & 51 & 49 & 49 & 54 & 58 \\
\hline Starch & 355 & 339 & 316 & 375 & 351 & 327 & 408 & 383 & 360 & 45 \\
\hline Sugar & 47 & 44 & 39 & 45 & 41 & 37 & 33 & 33 & 28 & 26 \\
\hline NDF & 152 & 170 & 194 & 149 & 180 & 200 & 147 & 168 & 201 & 478 \\
\hline $\mathrm{ADF}$ & 52 & 62 & 68 & 63 & 60 & 68 & 58 & 56 & 67 & 179 \\
\hline Lys & 14.9 & 15.0 & 15.4 & 13.6 & 13.9 & 13.4 & 10.7 & 10.3 & 10.0 & 8.2 \\
\hline Met & 4.7 & 5.2 & 4.5 & 4.6 & 4.6 & 4.6 & 3.7 & 3.8 & 3.9 & 4.9 \\
\hline Cys & 3.7 & 3.9 & 3.7 & 3.5 & 3.7 & 3.8 & 3.4 & 3.5 & 3.6 & 5.9 \\
\hline Thr & 8.3 & 8.4 & 7.8 & 7.5 & 7.4 & 7.5 & 7.1 & 6.7 & 6.6 & 10.1 \\
\hline $\operatorname{Trp}$ & 2.6 & 2.5 & 2.4 & 2.4 & 2.2 & 2.3 & 2.0 & 2.0 & 1.9 & 3.2 \\
\hline Val & 10.2 & 10.1 & 9.3 & 9.5 & 9.1 & 9.4 & 8.9 & 8.6 & 8.6 & 14.4 \\
\hline Ile & 9.2 & 8.9 & 8.0 & 8.4 & 8.0 & 8.1 & 7.9 & 7.4 & 7.2 & 11.6 \\
\hline Leu & 18.1 & 17.8 & 16.4 & 16.4 & 16.1 & 16.3 & 17.9 & 17.4 & 17.4 & 24 \\
\hline $\operatorname{Arg}$ & 14.8 & 14.1 & 11.9 & 13.5 & 12.5 & 12.0 & 11.8 & 11.1 & 10.0 & 13.7 \\
\hline $\mathrm{Ca}$ & 8.6 & 9.1 & 9.3 & 8.7 & 8.7 & 9.1 & 7.8 & 8.0 & 8.2 & 1.5 \\
\hline $\mathrm{P}$ & 5.9 & 5.9 & 6.1 & 6.0 & 6.0 & 6.1 & 5.4 & 5.3 & 5.4 & 9.6 \\
\hline $\mathrm{Na}$ & 0.9 & 1.2 & 1.4 & 1.1 & 1.2 & 1.4 & 1.0 & 1.2 & 1.3 & 5.9 \\
\hline
\end{tabular}

* Calculated according to GfE (1999) 
giblets (weight of empty gizzard, liver without gall bladder and heart immediately after slaughter) were assessed.

From 72 representing broilers ( 6 male and 6 female per treatment), whole bone-less breast meat samples were removed 24-h post mortem and stored at $-20{ }^{\circ} \mathrm{C}$ until analyses.

For the sensory analysis of chicken breast meat, a consumer-based sensory panel of six testing persons experienced in sensory evaluation was used. Chicken breasts were thawed to $2{ }^{\circ} \mathrm{C}$ for $24 \mathrm{~h}$ before sensory testing. Untreated $1-\mathrm{cm}$ thick breast meat pieces were grilled well-done for $4 \mathrm{~min}$ on each side in individual dishes at maximum power (Raclette Gourmet Grill Deluxe, Tefal S.A.S., Rumilly, France). Water and unsalted crackers were provided, and panelists were asked to expectorate and rinse their mouths between each sample. Each panelist was asked to evaluate six coded chicken breast samples per session (i.e., 12 sessions in total, performed on 2 days), one sample from each treatment, for tenderness, juiciness, and flavor, using a six-point hedonic scale, in which $1=$ very tough/very dry/dislike extremely and $6=$ very tender/very juicy/like extremely.
Chemical analyses in meat samples: The remaining raw breast meat samples without skin were freeze dried to determine the DM content. Subsequently, lyophilized meat samples were homogenized and the amount of $\mathrm{CP}$ and $\mathrm{EE}$ was analyzed by applying standard methods (Naumann and Bassler, 2012). For the determination of fatty acid profile, the one-step methylation method by Sukhija and Palmquist (1988) was applied. Briefly, $0.5 \mathrm{~g}$ of freeze-dried meat samples was extracted and converted to methyl esters for $2 \mathrm{~h}$ at $70{ }^{\circ} \mathrm{C}$ with toluene and $5 \%$ fresh methanolic $\mathrm{HCl}$ using nonadecanoic acid (C19:0, Sigma Aldrich, Munich, Germany) as internal standard. Subsequently, $5 \mathrm{ml}$ of $6 \%$ $\mathrm{K}_{2} \mathrm{CO}_{3}$ was added followed by another $2 \mathrm{ml}$ of toluene. After centrifugation, $1 \mu \mathrm{l}$ of the organic layer (split 50:1) was analyzed on a gas chromatograph (Agilent Technologies 7890A, Waldbronn, Germany) equipped with an automatic sampler 7693, an Agilent HP-88 capillary column $(100 \mathrm{~m} \times 0.25 \mathrm{~mm}$ of internal diameter and $0.2 \mu \mathrm{m}$ film thickness), and flame ionization detector (FID). The flow rates of the carrier gases (hydrogen and synthetic air) were

Table 3. Analyzed fatty acid profile of the diets, the pure DDGS, and vegetable oil ( $\mathrm{g} / \mathrm{kg}$ as fed)

Tabelle 3. Analysiertes Fettsäuremuster der Versuchsfuttermischungen, der Trockenschlempe (DDGS) und des Futterfettes (g/kg Frischmasse)

\begin{tabular}{|c|c|c|c|c|c|c|c|c|c|c|c|}
\hline \multirow[b]{2}{*}{$\%$ DDGS } & \multicolumn{3}{|c|}{ Starter diet } & \multicolumn{3}{|c|}{ Grower diet } & \multicolumn{3}{|c|}{ Finisher diet } & \multirow[t]{2}{*}{$\mathrm{DDGS}^{1}$} & \multirow[t]{2}{*}{$\mathrm{Oil}^{2}$} \\
\hline & 8 & 16 & 24 & 8 & 16 & 24 & 8 & 16 & 24 & & \\
\hline $\mathrm{SFA}^{3}$ & 16.16 & 17.78 & 20.08 & 19.73 & 21.98 & 24.01 & 16.11 & 17.57 & 21.27 & 13.54 & 107.49 \\
\hline MUFA $^{4}$ & 23.68 & 26.04 & 30.28 & 29.57 & 30.69 & 29.73 & 20.71 & 21.71 & 26.20 & 11.16 & 342.41 \\
\hline PUFA $^{5}$ & 31.08 & 34.75 & 40.06 & 36.45 & 40.30 & 44.81 & 32.44 & 35.11 & 42.54 & 35.40 & 419.66 \\
\hline PUFA:SFA & 1.92 & 1.95 & 1.99 & 1.85 & 1.83 & 1.87 & 2.01 & 2.00 & 2.00 & 2.62 & 3.90 \\
\hline C12:0 & 0.81 & 0.90 & 1.09 & 1.15 & 1.76 & 3.60 & 2.11 & 2.30 & 2.84 & 1.68 & 9.26 \\
\hline $\mathrm{C} 14: 0$ & 0.41 & 0.47 & 0.57 & 0.57 & 0.79 & 1.37 & 0.79 & 0.87 & 1.09 & 0.07 & 4.11 \\
\hline $\mathrm{C} 16: 0$ & 10.26 & 11.58 & 13.35 & 12.47 & 13.82 & 13.72 & 9.48 & 10.41 & 12.65 & 10.47 & 68.89 \\
\hline $\mathrm{C} 16: 1$ & 1.28 & 1.02 & 0.94 & 1.10 & 0.95 & 1.32 & 1.16 & 0.83 & 0.60 & 0.18 & n.d. ${ }^{6}$ \\
\hline C18:0 & 2.82 & 3.06 & 3.54 & 3.47 & 3.92 & 4.34 & 2.75 & 2.92 & 3.64 & 1.04 & 25.24 \\
\hline $\mathrm{C} 18: \ln 9$ & 20.99 & 23.45 & 27.51 & 26.75 & 27.95 & 26.80 & 18.46 & 19.70 & 24.16 & 10.00 & 325.00 \\
\hline $\mathrm{C} 18: \ln 7$ & 1.16 & 1.27 & 1.48 & 1.42 & 1.46 & 1.30 & 0.88 & 0.95 & 1.14 & 0.66 & 17.41 \\
\hline $\mathrm{C} 18: 2$ & 29.18 & 32.65 & 37.63 & 34.18 & 38.00 & 42.73 & 30.99 & 33.51 & 40.65 & 33.24 & 388.57 \\
\hline $\mathrm{C} 18: 3 \mathrm{n} 3$ & 1.90 & 2.10 & 2.42 & 2.27 & 2.31 & 2.08 & 1.45 & 1.60 & 1.90 & 2.16 & 31.09 \\
\hline C20:0 & 0.29 & 0.32 & 0.36 & 0.35 & 0.38 & 0.35 & 0.25 & 0.26 & 0.33 & 0.14 & n.d. \\
\hline C20:1 & 0.25 & 0.29 & 0.35 & 0.31 & 0.34 & 0.31 & 0.21 & 0.23 & 0.30 & 0.31 & n.d. \\
\hline
\end{tabular}

${ }^{1}$ Wheat-corn-DDGS (Agrana, Pischelsdorf, Austria)

${ }^{2}$ Unifrutol" (Garant, Pöchlarn, Austria)

${ }^{3}$ SFA is the sum of saturated fatty acids $(\mathrm{C} 12: 0+\mathrm{C} 14: 0+\mathrm{C} 16: 0+\mathrm{C} 18: 0+\mathrm{C} 20: 0)$

${ }^{4}$ MUFA is the sum of monounsaturated fatty acids $(\mathrm{C} 16: 1+\mathrm{C} 18: 1 \mathrm{n} 9+\mathrm{C} 18: 1 \mathrm{n} 7+\mathrm{C} 20: 1)$

${ }^{5}$ PUFA is the sum of polyunsaturated fatty acids (C18:2 + C18:3n3)

${ }^{6}$ n.d., not detected 
35 and $350 \mathrm{ml} \mathrm{min}{ }^{-1}$, respectively. Conditions: The injection port temperature and the detection temperature were $250{ }^{\circ} \mathrm{C}$. Oven temperature was ramped to $170{ }^{\circ} \mathrm{C}$ for $1 \mathrm{~min}$ followed by an increase to $200{ }^{\circ} \mathrm{C}$ at $2{ }^{\circ} \mathrm{C} \mathrm{min}^{-1}$. After $1 \mathrm{~min}$ at $200{ }^{\circ} \mathrm{C}$, temperature was increased by $8{ }^{\circ} \mathrm{C} \mathrm{min}{ }^{-1}$ to $230^{\circ} \mathrm{C}$, which was held for another $10 \mathrm{~min}$. Commercial standard fatty acid methyl esters (FAME) mixtures (Supelco 37 Component FAME Mix, Supelco, Pennsylvania, USA) were used for the identification of individual fatty acids.

\subsection{Statistical analyses}

All experimental data were statistically analyzed by the general linear model (GLM) procedure of SAS 9.1.3 (SAS, Inst., Inc., Cary, NC, USA) by applying the following model: $y_{\mathrm{ijk}}=\mu+\alpha_{\mathrm{i}}+\beta_{\mathrm{j}}+\alpha^{*} \beta_{\mathrm{ij}}+\mathrm{e}_{\mathrm{ijk}}\left(\mathrm{y}_{\mathrm{ijk}}\right.$ is the dependent variable, $\mu$ is the overall mean, $\alpha_{i}$ the effect of DDGS concentration ( $i=1,2,3), \beta_{j}$ is the effect of NSP-hydrolyzing enzyme supplementation $(j=1,2), \alpha^{*} \beta_{\mathrm{ij}}$ is the effect of interaction of DDGS concentration and NSP-hydrolyzing enzyme supplementation, $\mathrm{e}_{\mathrm{i} j \mathrm{k}}$ is the residual experimental error). Treatment effects were determined by analysis of variance (ANOVA) using the Tukey-Kramer test in case of a significant interaction. For performance, energy parameters, and digestibility, the pen served as experimental unit, whereas for carcass characteristics and meat quality parameters, the individual animal was the experimental unit. Tables 4-9 present the least squares (LS)-mean (except for organoleptic parameters, where means were used) values of the different dietary treatments and the pooled standard error of means (SEM). For the statistical evaluation of the organoleptic tests, the Wilcoxon range test was applied. Significant differences among means $(p<0.05)$ are indicated by different superscripts; trends are reported at $p<0.1$. Pearson correlation coefficient was determined for selected parameters.

Table 4. Zootechnical performance of broiler chicks

Tabelle 4. Zootechnische Leistungen der Broiler

\begin{tabular}{|c|c|c|c|c|c|c|c|c|c|}
\hline & \multicolumn{3}{|c|}{ DDGS } & \multicolumn{2}{|c|}{ NSP enzyme } & \multirow[t]{2}{*}{ SEM } & \multicolumn{3}{|c|}{$p$-value } \\
\hline & 8 & 16 & 24 & - & + & & DDGS & Enzyme & $\begin{array}{c}\text { DDGS } \times \\
\text { Enzyme }\end{array}$ \\
\hline \multicolumn{10}{|c|}{ Fattening performance day $1-14$ (starter phase) } \\
\hline $\mathrm{BW}$, day $1, \mathrm{~g}$ & 43.1 & 43.1 & 43.1 & 43.1 & 43.1 & 0.07 & 0.986 & 0.812 & 0.939 \\
\hline BW, day $14, \mathrm{~g}$ & 430.4 & 442.7 & 435.8 & 435.3 & 437.4 & 3.77 & 0.522 & 0.808 & 0.876 \\
\hline ADG, g day $^{-1}$ & 26.5 & 28.3 & 27.3 & 27.5 & 27.3 & 0.34 & 0.149 & 0.741 & 0.744 \\
\hline ADFI, g day ${ }^{-1}$ & 36.2 & 37.0 & 35.9 & 36.8 & 35.9 & 0.33 & 0.462 & 0.209 & 0.714 \\
\hline FCR, $\mathrm{g} \mathrm{g}^{-1}$ & $1.37^{(a)}$ & $1.31^{(\mathrm{b})}$ & $1.32^{(\mathrm{ab})}$ & 1.34 & 1.32 & 0.01 & 0.044 & 0.239 & 0.856 \\
\hline \multicolumn{10}{|c|}{ Fattening performance day 14-28 (grower phase) } \\
\hline BW, day $28, \mathrm{~g}$ & 1,404 & 1,448 & 1,408 & 1,402 & 1,439 & 11.5 & 0.244 & 0.125 & 0.587 \\
\hline ADG, g day ${ }^{-1}$ & 69.2 & 71.8 & 69.3 & 69.0 & 71.2 & 0.66 & 0.212 & 0.099 & 0.643 \\
\hline ADFI, g day ${ }^{-1}$ & 112.6 & 115.3 & 112.2 & 113.7 & 113.1 & 0.89 & 0.303 & 0.723 & 0.617 \\
\hline FCR, $\mathrm{g} \mathrm{g}^{-1}$ & 1.63 & 1.61 & 1.62 & 1.65 & 1.59 & 0.01 & 0.761 & 0.016 & 0.824 \\
\hline \multicolumn{10}{|c|}{ Fattening performance day 28-36 (finisher phase) } \\
\hline BW, day $36, \mathrm{~g}^{1}$ & 2,078 & 2,118 & 2,059 & 2,059 & 2,111 & 14.4 & 0.240 & 0.044 & 0.176 \\
\hline $\mathrm{ADG}^{2}, \mathrm{~g} \mathrm{day}^{-1}$ & 85.3 & 84.3 & 82.2 & 82.1 & 85.8 & 0.86 & 0.104 & 0.005 & $0.008^{2}$ \\
\hline ADFI, $\mathrm{g} \mathrm{day}^{-1}$ & 167.9 & 171.1 & 168.4 & 166.9 & 171.4 & 1.31 & 0.500 & 0.074 & 0.386 \\
\hline $\mathrm{FCR}^{3}, \mathrm{~g} \mathrm{~g}^{-1}$ & $1.97^{\mathrm{b}}$ & $2.03^{a(b)}$ & $2.05^{\mathrm{a}}$ & 2.03 & 2.00 & 0.02 & 0.015 & 0.074 & $0.025^{3}$ \\
\hline \multicolumn{10}{|c|}{ Fattening performance day $1-36$} \\
\hline ADG, $\mathrm{g} \mathrm{day}^{-1}$ & $54.7^{(\mathrm{b})}$ & $57.2^{(a)}$ & $55.1^{(\mathrm{ab})}$ & 55.1 & 56.3 & 0.47 & 0.073 & 0.197 & 0.911 \\
\hline ADFI, g day ${ }^{-1}$ & 93.1 & 96.5 & 94.2 & 94.5 & 94.6 & 0.75 & 0.162 & 0.946 & 0.882 \\
\hline FCR, $\mathrm{g} \mathrm{g}^{-1}$ & 1.66 & 1.75 & 1.77 & 1.75 & 1.70 & 0.01 & 0.749 & 0.733 & 0.221 \\
\hline
\end{tabular}




\section{Results and discussion}

\subsection{Feed analyses}

Analyzed nutrient concentrations of starter, grower, and finisher diets are presented in Table 2 . The results of fatty acid profile of the diets as well as the applied pure DDGS and vegetable oil are presented in Table 3. On an average, the EE content and accordingly the absolute amount of fatty acids increased by $9 \%$ and $30 \%$, with the dietary rise in DDGS to $16 \%$ and $24 \%$ (and concomitant oil supplementation), respectively, compared to diet DDGS 8\%. Values were within the expected range.

Unlike the results of Heincinger et al. (2012), in which the relative amount of dietary linoleic acid increased by $5.1 \%$ when increasing DDGS content by 15\% (replacing soybean-meal and wheat), increases from 8\% DDGS to $24 \%$ DDGS in our study only resulted in a relative increase of $0.9 \%$ in finisher diet (data not shown).

\subsection{Zootechnical performance and carcass parameters}

The performance results of broilers during the experimental period are shown in Table 4. Starting with homogeneous distribution of BWs, BW, ADG, and ADFI did not differ among treatment groups $(p>0.05)$ in the starter period. Diets containing 16\% DDGS showed an improved FCR compared to diets including $8 \%$ DDGS $(-4.4 \%)(p<0.05)$. In the grower period, enzyme supplementation improved ADG about $3.1 \%(p<0.1)$ and FCR about 3.8\% $(p<0.05)$. However, increasing DDGS content showed no effect on performance in the grower phase. In the finisher period, a high DDGS supplementation increased the FCR up to $4.0 \%$ compared to the diet with the lowest DDGS addition $(p<0.05)$. The NSP-Enzyme increased BW about 2.5\% $(p<0.05)$, ADG about $4.8 \%(p<0.05)$, and ADFI about 2.6\% $(p<0.1)$ and decreased FCR about $1.5 \%(p<0.1)$. For ADG and FCR, significant interactions between DDGS and enzyme supplementation were observed $(p<0.05)$, indicating a more pronounced enzyme effect in the low-DDGS diets. Over the whole fattening period, performance was unaffected by DDGS and enzyme supplementation.

Our results show that an increasing DDGS content had no effect on ADG, ADFI, and FCR during the whole fattening period, provided that a sufficient supply with digestible amino acids (dAA) to cover requirements is warranted. Other studies based on the similar study design confirm the present observations (Oryschak et al., 2010). Nevertheless, other authors reported decreases in ADG and ADFI by increasing DDGS content (Lumpkins et al., 2004, Schedle et al., 2010a). A possible reason for the decline in performance of those studies might be the formulation of AA on basis of total AA without consideration of their digestibility (Whitney and Shurson, 2004).

Raising amounts of DDGS by expense of corn and soybean meal enhances the NSP content in feed (Widmer et al., 2008; Schedle et al., 2010b). Supplementation of NSP-degrading enzymes to diets containing high amounts of NSP or rather fiber is of interest to increase the potential for use of fiber-rich industrial by-product such as DDGS in the diet of monogastric animals (Zijlstra et al., 2010). In the present study, enzyme supplementation led to an enhanced ADG in the finisher phase and final BW. Additionally, the NSP-hydrolyzing enzyme complex improved FCR in the grower $(p<0.05)$ and finisher phases $(p<0.1)$. It is well established that NSP-hydrolyzing enzymes can improve FCR in fiber-rich diets as reviewed by Slominsky (2011) and Woyengo and Nyachoti (2011). However, especially young broilers seem to tolerate or even require moderate amounts of fiber for gastrointestinal tract development (Jiménez-Moreno et al., 2009). This may be the reason for the lack of performance improvements in the starter phase with NSP-hydrolyzing enzyme supplementation. Interestingly, an interaction between DDGS and NSP-hydrolyzing enzymes was observed in the finisher phase as well as for heart and liver weight, as described below.

\subsection{Energy and digestibility parameters}

No differences between treatments were detected regarding the $\mathrm{AME}_{\mathrm{N}}$ content of diets (Table 5). The energy content reached 11.5 $\mathrm{MJ} \mathrm{AME}_{\mathrm{N}} \mathrm{kg}^{-1}$, on an average. Nevertheless, these values are lower than the calculated energy contents. Similar effects were observed for the parameters energy intake per day and energy/gain. Neither DDGS nor enzyme supplementation affected $\mathrm{N}$ retention and total tract apparent retention of DM.

The replacement of soybean meal and corn by dietary DDGS inclusion demands an increase in vegetable oil addition in the broiler diet to keep the energy level constant (Thacker and Widyaratne, 2007; Schedle et al., 2010a). It is well known that increasing oil levels, altered oil/fat composition of diets, as well as fiber content can affect nutrient digestibility in broilers. This may result from alteration in transit time, mucosal architecture, and activity of digestive enzymes, especially proteases (Ketels and DeGrote, 1989; Jiménez-Moreno et al., 2009; Honda et al., 2010). Howev- 
er, $\mathrm{AME}_{\mathrm{N}}$ content, DM digestibility, and apparent $\mathrm{N}$ retention did not differ between treatments. Similar observations were made by Crespo and Esteve-Garcia (2002). Other authors reported a decrease in protein digestibility by increasing oil content (Leytem et al., 2008; Honda et al., 2010). The dietary fatty acid profile has a strong impact on energy, nitrogen, and fatty acid deposition in broiler chickens (Crespo and Esteve-Garcia, 2002). Hence, both the increase in dietary oil and the concomitant raise in unsaturation of dietary fatty acids might be a reason for the unaltered apparent $\mathrm{N}$ retention in the finisher phase of our study.

Furthermore, Oryschak et al. (2010) found interactions between triticale DDGS and NSP-hydrolyzing enzymes in broiler diets. In their study, apparent ileal digestibility of CP and several AA increased with enzyme supplementation in diets containing 15\% DDGS but not in diets with 30\% DDGS inclusion. The difference between the treatments with and without enzyme in the low DDGS diet $(8 \%)$ in our study might indicate an improved effect of the enzyme on the non-DDGS diet components in our study. The inclusion of similar NSP-degrading enzymes in the production process of the applied DDGS product may be an explanation for the absence of distinct effects of the NSP-hydrolyzing enzyme supplemented in the diet on performance in high DDGS groups.

\subsection{Carcass characteristics}

Carcass characteristics are shown in Table 6. Diets containing $16 \%$ DDGS had significantly higher dressing percentage compared to treatments with 8\% DDGS $(p<0.05)$. Gizzard weight was significantly higher in the treatment with the highest DDGS concentration compared to the low DDGS $\operatorname{diet}(p<0.05)$. It is well described in literature that the inclu- sion of insoluble fiber sources in the diet increases the retention time of the digesta in the upper part of the digestive tract which in turn might stimulate gizzard development (González-Alvarado et al., 2010). Increasing fiber content or $24 \%$ DDGS in diet reduced remainder of carcass percentage compared to treatment including $8 \%$ DDGS $(p<0.05)$. The trend of heavier BW affected by enzyme supplementation was also observed for carcass bodies $(p<0.1)$. Furthermore, livers of enzyme-supplemented broilers were significantly heavier than those of non-supplemented animals $(p<0.05)$. However, heart and liver weights showed a significant interaction between DDGS and enzyme $(p<0.05)$. Thus, enzyme supplementation enhanced weight of liver and heart predominantly in the low DDGS group $(+5.8 \%$; $p<0.05)$. González-Alvarado et al. (2008) and Gracia et al. (2009) observed higher relative liver weight when broiler were fed heattreated cereals. The authors hypothesized that this increase may either result from a higher digesta viscosity or improved availability of dietary fat, which in turn may stimulate the liver in secreting biliary juices. Hence, the improved FCR and, therefore, also the energy per kilogram demand in the finisher phase can be associated with the liver weights. This suggestion is further supported by the strong negative correlation between the FCR and energy per kilogram, respectively, and the liver weight (correlation coefficient: $-0.72 ;-0.65$; $p<0.0001)$ in the finisher phase.

\subsection{Crude nutrients, sensory analyses and fatty acid profile of breast meat}

Increasing DDGS and vegetable oil contents had no influence on crude nutrient contents of raw breast meat (Table 7). However, enzyme addition resulted in a significant reduction of $\mathrm{EE}$ and a concomitant increase in $\mathrm{CP}$ (\% DM).

Table 5. Energy parameters, apparent $\mathrm{N}$ retention, and DM digestibility in finisher phase

Tabelle 5. Energieparameter, N-Retention und Trockenmasseverdaulichkeit in der Finisherphase

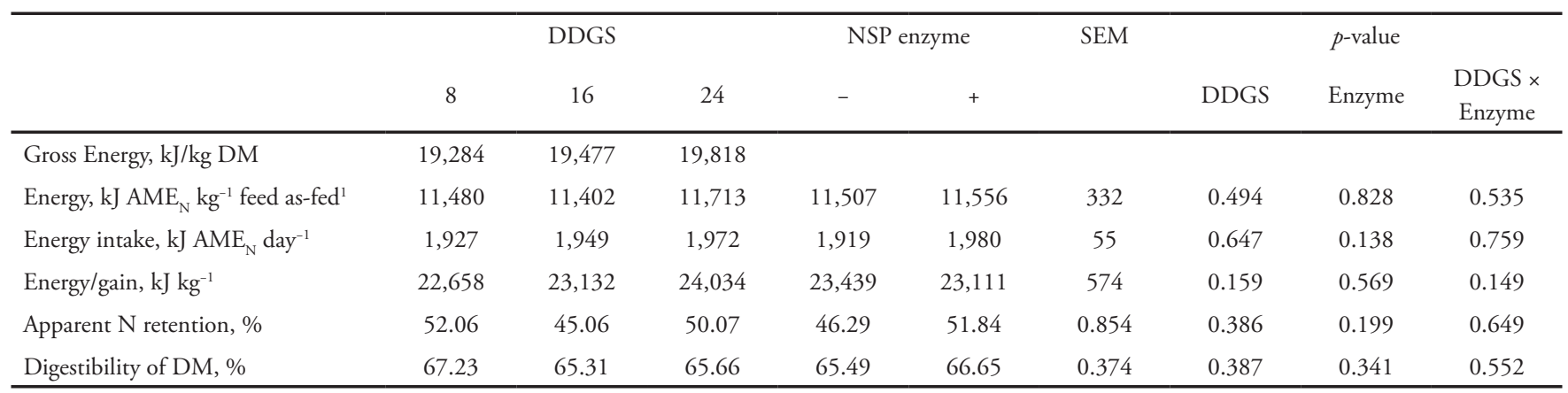

${ }^{1}$ Calculated according to Hill and Anderson (1958) and GfE (1999) 
Thus, enzyme addition resulted in less intramuscular fat content in breast meat, indicating a potentially preferential utilization of dietary energy for protein retention. However, while apparent $\mathrm{N}$ retention was only numerically increased with enzyme addition, CP (\%DM) content in breast meat was significantly higher $(p<0.05)$. Based on these results, the improved FCR affected by enzyme supplementation without effect on digestibility likewise seems to be due to intermediate metabolism processes. As described by Fernandez et al. (1999), fat is responsible for organoleptic properties of meat and has a distinct effect on juiciness (Wood et al., 2003). However, we could not show that lower intramuscular fat content correlates with a decrease in the sensation of juiciness (correlation coefficient $0.14, p>0.1$ ).

In this respect, sensory analyses showed a trend of high DDGS diets to increase meat tenderness $(p<0.1$, Table 8 ), whereas the enzyme addition led to lower juiciness of breast meat samples $(p<0.1)$. In general, mean organoleptic determination of flavor in meat samples resulted in a mean value of 3.44 without the influence of experimental factors, DDGS or enzymes.

The influence of DDGS and vegetable oil on fatty acid composition (Table 9) was primarily seen in a significant increase in the amount of polyunsaturated fatty acids (PUFAs) in a linear manner. Furthermore, the significant increase in PUFA-to-saturated fatty acid (SFA) ratio shows that this increase goes along with a significant decrease in SFA $(p<0.05)$. The relative amount of monounsaturated fatty acid (MUFA) was significantly reduced by increasing DDGS and vegetable oil in broiler diets. In detail, increases resulted from a significant increase in total n6-fatty acids with only minor influence on total $\mathrm{n} 3$-fatty acids $(p<0.1)$. Thus, especially, linoleic (C18:2 n6) acid was significantly increased in high DDGS diets. Consequently, the n6-to-n3 ratio augmented as well by $11.3 \%$ because of the DDGS and vegetable oil increase in diet $(p<0.0001)$. The reduction in MUFA concentration derives primarily from a significant reduction of oleic acid (C18:1 n9) in the 24\% DDGS fed broilers. Like with DDGS increase, a significant decrease in MUFAs and an increase in PUFAs (n6 but not n3) $(p<0.05)$ were also observed due to the addition of NSP-hydrolyzing enzyme. However, as the percentage of SFA remained uninfluenced, no significant changes in PUFA-to-SFA ratio could be detected for enzyme supplementation $(p>0.1)$. Even though several significant changes because of DDGS or enzyme addition

Table 6. Results of carcass parameters and dividing chilled carcasses into carcass parts

Tabelle 6. Ergebnisse der Schlachtleistung sowie der Teilstückanalyse

\begin{tabular}{|c|c|c|c|c|c|c|c|c|c|}
\hline & \multicolumn{3}{|c|}{ DDGS } & \multicolumn{2}{|c|}{ NSP enzyme } & \multirow[t]{2}{*}{ SEM } & \multicolumn{3}{|c|}{$p$-value } \\
\hline & 8 & 16 & 24 & - & + & & DDGS & Enzyme & $\begin{array}{l}\text { DDGS } \times \\
\text { Enzyme }\end{array}$ \\
\hline \multicolumn{10}{|c|}{ Carcass parameters } \\
\hline Dressing, $\%$ & $78.1^{\mathrm{b}}$ & $78.7^{\mathrm{a}}$ & $78.4^{\mathrm{ab}}$ & 78.4 & 78.4 & 0.08 & 0.006 & 0.640 & 0.064 \\
\hline Eviscerated carcass, $\mathrm{g}$ & 1627.4 & 1666.1 & 1613.9 & 1616.5 & 1655.1 & 11.92 & 0.110 & 0.070 & 0.098 \\
\hline Chilled carcass, $\mathrm{g}$ & 1605.6 & 1643.9 & 1592.0 & 1594.5 & 1633.3 & 11.74 & 0.104 & 0.064 & 0.086 \\
\hline Carcass for grilling, $\mathrm{g}$ & 1447.6 & 1481.7 & 1432.8 & 1435.6 & 1472.4 & 10.75 & 0.108 & 0.062 & 0.080 \\
\hline Abdominal fat, $g$ & 34.5 & 36.0 & 35.0 & 34.9 & 35.4 & 0.51 & 0.483 & 0.584 & 0.442 \\
\hline Heart $^{1}, g$ & 9.53 & 9.38 & 9.33 & 9.28 & 9.54 & 0.08 & 0.456 & 0.054 & 0.034 \\
\hline Liver $^{2}, \mathrm{~g}$ & 43.6 & 42.1 & 41.8 & 41.3 & 43.7 & 0.39 & 0.100 & 0.001 & $<0.001$ \\
\hline Gizzard, $g$ & $25.4^{\mathrm{b}}$ & $26.3^{\mathrm{ab}}$ & $26.6^{a}$ & 26.0 & 26.2 & 0.21 & 0.042 & 0.588 & 0.559 \\
\hline \multicolumn{10}{|c|}{ Relative proportion (\%) of carcass parts compared to the carcass for grilling } \\
\hline Breast & 27.5 & 27.6 & 28.4 & 27.8 & 28.0 & 0.266 & 0.181 & 0.649 & 0.623 \\
\hline Legs & 27.7 & 28.5 & 28.4 & 28.5 & 27.9 & 0.226 & 0.213 & 0.127 & 0.803 \\
\hline Wings & 10.9 & 10.5 & 10.5 & 10.6 & 10.7 & 0.101 & 0.184 & 0.568 & 0.291 \\
\hline Remainder of carcass & $33.8^{\mathrm{a}}$ & $33.2^{\mathrm{ab}}$ & $32.2^{\mathrm{b}}$ & 33.0 & 33.1 & 0.233 & 0.009 & 0.732 & 0.623 \\
\hline
\end{tabular}


were observed for fatty acid profile, no significant interaction between the factors occurred.

Unlike in our findings, where high DDGS diets affected a more tender breast meat $(p<0.1)$, Schilling et al. (2010) showed increased shear force values for broiler breast meat fed up to $24 \%$ DDGS. Higher PUFA concentrations in fat go in line with increased softness of the fat in meat (Wood et al. 2003); however, the amount of PUFA as well as total fat content in breast meat may have been too low to correlate with the tenderness sensation (correlation coefficient of parameter PUFA and tenderness: $0.13, p>0.1$ ) in our study. However, sensory analysis revealed that flavor and overall consumer acceptability was uninfluenced by DDGS addition (Schilling et al., 2010). Studies showed that the absolute fat content of breast meat remained uninfluenced by the increase in DDGS (Schilling et al., 2010) or PUFA concentration (Cortinas et al., 2004) in broiler diet. These findings are in accordance with our study.

Former trials showed that dietary PUFAs - in contrast to SFA or MUFA - decrease abdominal fat in broilers (Crespo and Esteve-Garcia, 2002). However, absolute increases in dietary PUFA content $(+10.2 \%$ and $+27.7 \%$ in $16 \%$ DDGS and 24\% DDGS compared to 8\% DDGS, respectively, Table 3) in the present diets did not affect abdominal fat tissue. This may be caused by the concomitant absolute increase in dietary SFA content of diet in a comparable manner $(+10.2 \%$ and $+26.0 \%$, respectively) resulting in similar dietary PUFA-to-SFA ratios with a mean value of $1.94 \pm 0.02$. Furthermore, the energy intake as well as the $\mathrm{N}$ metabolism was similar between the treatments.

The composition of fatty acids in chicken tissues results from direct deposition of dietary fatty acids and endogenous fat synthesis (Cortinas et al. 2004). A general lipogenesis inhibition by dietary fat addition but a comparably higher endogenous synthesis is reported in broilers fed diets rich in PUFAs (Crespo and Esteve-Garcia, 2002). In our study, an increase in linoleic acid and total PUFA content because of increasing dietary DDGS supply up to $24 \%$ (and increased vegetable oil concentrations for isocaloric diets) in breast meat was observed. Schilling et al. (2010) and Heincinger et al. (2012) reported similar findings in broiler thigh and turkey breast, respectively. Furthermore, Corzo et al. (2009) also found increases in eicosadienoic acid (C20:2) with DDGS. However, unlike in the study of Schilling et al. (2010), we did not observe reductions in stearic acid in our breast meat samples. This discrepancy may result from differences in sampling site or origin of DDGS and dietary oil.

Although the PUFA-to-SFA ratio remained quite constant in feed despite increases in DDGS and fat content, only the PUFA family was incorporated in a higher manner in the intramuscular fat content. This is mirrored in a $14.6 \%$

Table 7. Crude nutrient content of breast meat samples without skin (\% DM)

Tabelle 7. Rohnährstoffgehalte der Brustfleischproben ohne Haut (\% Trockenmasse)

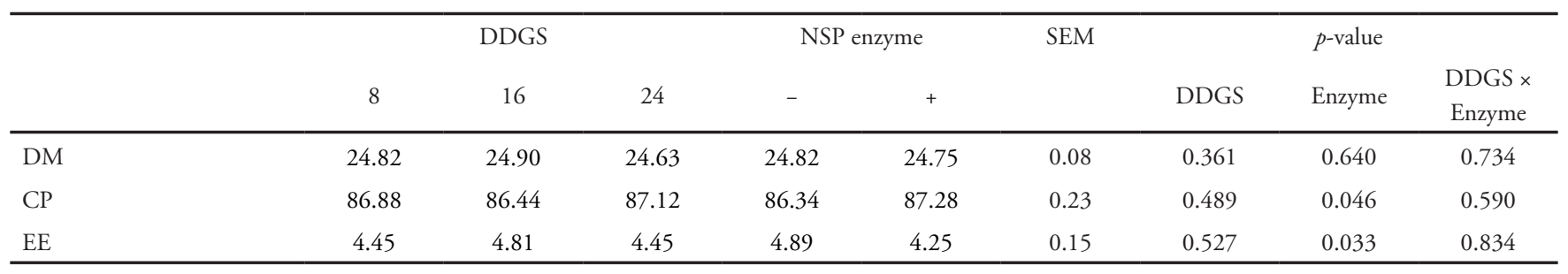

DM, dry matter; CP, crude protein; EE, ether extract

Table 8. Results of the organoleptic testing panel

Tabelle 8. Organoleptische Untersuchung der Brustfleischproben

\begin{tabular}{|c|c|c|c|c|c|c|c|c|}
\hline & \multicolumn{3}{|c|}{ DDGS } & \multicolumn{2}{|c|}{ NSP enzyme } & \multirow[t]{2}{*}{ SEM } & \multicolumn{2}{|c|}{$p$-value } \\
\hline & 8 & 16 & 24 & - & + & & DDGS & Enzyme \\
\hline Tenderness* & $4.21^{(\mathrm{b})}$ & $4.24^{(\mathrm{b})}$ & $4.52^{(\mathrm{a})}$ & 4.39 & 4.26 & 0.06 & 0.053 & 0.295 \\
\hline Juiciness* & 3.98 & 4.01 & 4.19 & 4.16 & 3.96 & 0.06 & 0.306 & 0.074 \\
\hline Flavor* & 3.39 & 3.63 & 3.32 & 3.49 & 3.40 & 0.06 & 0.190 & 0.413 \\
\hline
\end{tabular}

* Based on a six-point hedonic scale: 1 = very tough/very dry/dislike extremely and 6 = very tender/very juicy/like extremely 
increase in PUFA-to-SFA ratio in meat (from 8\% DDGS to $24 \%$ DDGS, $p<0.0001$ ). Lopez-Ferrer et al. (2001) also showed that PUFAs are more likely changeable via dietary intervention than SFA and MUFA. This may result in part from the preferential inclusion rate of PUFAs in phospholipids (Hulan et al., 1988), of which the concentration is high in breast meat fat (Ratnayake et al., 1989). As reviewed by De Smet et al. (2004), the absolute intra- muscular fat level has a major impact on the fatty acid profile, showing higher PUFA contents in leaner meat samples. This was also observed in our study feeding broiler with diets supplemented with NSP-hydrolyzing enzymes. Generally, an increase in PUFAs without concomitant increases in SFA and MUFA is a positive development concerning physiological fat quality. However, as the increase is more pronounced in the $\mathrm{n} 6$ fraction, the balance of $\mathrm{n} 6$

Table 9. Fatty acid profile of breast meat samples without skin (\% FAME)

Tabelle 9. Fettsäuremuster der Brustfleischproben ohne Haut (\% Fettsäuremethylester)

\begin{tabular}{|c|c|c|c|c|c|c|c|c|c|}
\hline & \multicolumn{3}{|c|}{ DDGS } & \multicolumn{2}{|c|}{ NSP enzyme } & \multirow[t]{2}{*}{ SEM } & \multicolumn{3}{|c|}{$p$-value } \\
\hline & 8 & 16 & 24 & - & + & & DDGS & Enzyme & $\begin{array}{c}\text { DDGS } \times \\
\text { Enzyme }\end{array}$ \\
\hline SFA & $30.29^{(a)}$ & $29.61^{(b)}$ & $29.65^{(b)}$ & 29.74 & 29.96 & 0.12 & 0.033 & 0.354 & 0.799 \\
\hline MUFA & $35.84^{a(b)}$ & $34.81^{(\mathrm{b})}$ & $32.23^{c}$ & 34.80 & 33.79 & 0.27 & $<0.0001$ & 0.011 & 0.894 \\
\hline PUFA & $33.94^{c}$ & $35.76^{\mathrm{b}}$ & $38,35^{a}$ & 35.52 & 36.51 & 0.28 & $<0.0001$ & 0.004 & 0.973 \\
\hline n3 & $1.98^{(\mathrm{ab})}$ & $1.91^{(\mathrm{b})}$ & $2.04^{(a)}$ & 1.95 & 2.00 & 0.02 & 0.098 & 0.248 & 0.455 \\
\hline n6 & $31.91^{c}$ & $33.67^{b}$ & $36.31^{\mathrm{a}}$ & 33.54 & 34.39 & 0.27 & $<0.0001$ & 0.010 & 0.886 \\
\hline n6:n3 & $16.21^{\mathrm{b}}$ & $17.69^{\mathrm{a}}$ & $18.04^{a}$ & 17.35 & 17.28 & 0.18 & $<0.0001$ & 0.837 & 0.297 \\
\hline PUFA:SFA & $1.13^{\mathrm{c}}$ & $1.20^{\mathrm{b}}$ & $1.29^{\mathrm{a}}$ & 1.20 & 1.22 & 0.01 & $<0.0001$ & 0.215 & 0.998 \\
\hline C12:0 & $0.58^{c}$ & $0.75^{\mathrm{b}}$ & $1.02^{\mathrm{a}}$ & 0.80 & 0.77 & 0.03 & $<0.0001$ & 0.386 & 0.731 \\
\hline C14:0 & $0.71^{\mathrm{c}}$ & $0.79^{\mathrm{b}}$ & $0.91^{a}$ & 0.82 & 0.78 & 0.01 & $<0.0001$ & 0.023 & 0.274 \\
\hline C14:1 & 2.33 & 2.14 & 2.15 & 2.14 & 2.26 & 0.06 & 0.340 & 0.321 & 0.828 \\
\hline C16:0 & $18.82^{a}$ & $18.45^{\mathrm{ab}}$ & $17.78^{\mathrm{b}}$ & 18.48 & 18.22 & 0.09 & $<0.0001$ & 0.105 & 0.906 \\
\hline C16:1 & $1.82^{\mathrm{a}}$ & $1.62^{\mathrm{a}}$ & $1.31^{\mathrm{b}}$ & 1.67 & 1.50 & 0.05 & $<0.0001$ & 0.026 & 0.750 \\
\hline C16:1t & $0.40^{\mathrm{ab}}$ & $0.42^{\mathrm{a}}$ & $0.37^{\mathrm{b}}$ & 0.40 & 0.40 & 0.01 & 0.017 & 0.648 & 0.987 \\
\hline $\mathrm{C} 17: 0$ & 0.75 & 0.71 & 0.74 & 0.71 & 0.76 & 0.02 & 0.761 & 0.155 & 0.861 \\
\hline $\mathrm{C} 17: 1$ & 0.77 & 0.68 & 0.69 & 0.67 & 0.75 & 0.02 & 0.076 & 0.026 & 0.872 \\
\hline C18:0 & 9.18 & 8.90 & 8.97 & 8.88 & 9.16 & 0.09 & 0.425 & 0.120 & 0.788 \\
\hline C18:1n9 & $27.77^{\mathrm{a}}$ & $27.28^{\mathrm{a}}$ & $25.30^{\mathrm{b}}$ & 27.31 & 26.25 & 0.25 & $<0.0001$ & 0.017 & 0.967 \\
\hline $\mathrm{C} 18: 1 \mathrm{n} 7$ & $2.33^{\mathrm{a}(\mathrm{b})}$ & $2.21^{(b)}$ & $2.05^{\mathrm{c}}$ & 2.22 & 2.17 & 0.03 & $<0.0001$ & 0.296 & 0.595 \\
\hline C18:2 & $23.52^{c}$ & $25.73^{\mathrm{b}}$ & $27.64^{a}$ & 25.66 & 25.60 & 0.27 & $<0.0001$ & 0.864 & 0.586 \\
\hline C18:3n3 & 0.98 & 1.04 & 1.04 & 1.02 & 1.01 & 0.02 & 0.144 & 0.731 & 0.880 \\
\hline C18:3n6 & 0.15 & 0.15 & 0.16 & 0.16 & 0.15 & 0.003 & 0.775 & 0.060 & 0.513 \\
\hline C20:0 & 0.123 & 0.119 & 0.122 & 0.118 & 0.124 & 0.001 & 0.406 & 0.015 & 0.892 \\
\hline C20:1 & $0.32^{\mathrm{a}}$ & $0.32^{a}$ & $0.29^{\mathrm{b}}$ & 0.30 & 0.31 & 0.004 & 0.002 & 0.421 & 0.472 \\
\hline C20:2 & $0.63^{\mathrm{b}}$ & $0.70^{\mathrm{ab}}$ & $0.77^{\mathrm{a}}$ & 0.66 & 0.74 & 0.02 & 0.003 & 0.015 & 0.982 \\
\hline C20:3 & $0.84^{a}$ & $0.71^{\mathrm{b}}$ & $0.68^{\mathrm{b}}$ & 0.72 & 0.77 & 0.02 & 0.0007 & 0.134 & 0.345 \\
\hline C20:4 & 5.18 & 4.89 & 5.25 & 4.93 & 5.28 & 0.12 & 0.451 & 0.155 & 0.895 \\
\hline C22:4 & 1.48 & 1.47 & 1.58 & 1.45 & 1.57 & 0.03 & 0.306 & 0.066 & 0.476 \\
\hline $\mathrm{C} 22: 5$ & 0.52 & 0.48 & 0.57 & 0.52 & 0.53 & 0.02 & 0.098 & 0.640 & 0.430 \\
\hline C22:6 & $0.48^{(a)}$ & $0.40^{(\mathrm{b})}$ & $0.42^{(\mathrm{ab})}$ & 0.41 & 0.45 & 0.01 & 0.076 & 0.150 & 0.963 \\
\hline C24:1 & $0.15^{a}$ & $0.13^{\mathrm{ab}}$ & $0.12^{\mathrm{b}}$ & 0.12 & 0.14 & 0.004 & 0.008 & 0.026 & 0.298 \\
\hline
\end{tabular}

SFA is the sum of saturated fatty acids (C12:0 + C14:0 + C16:0 + C17:0 + C18:0 + C20:0)

MUFA is the sum of monounsaturated fatty acids $(\mathrm{C} 14: 1+\mathrm{C} 16: 1+\mathrm{C} 16: 1 \mathrm{t}+\mathrm{C} 17: 1+\mathrm{C} 18: 1 \mathrm{n} 9+\mathrm{C} 18: 1 \mathrm{n} 7+\mathrm{C} 20: 1+\mathrm{C} 24: 1)$

PUFA is the sum of polyunsaturated fatty acids $(\mathrm{n} 3+\mathrm{n} 6)$

$\mathrm{n} 3=\mathrm{C} 18: 3 \mathrm{n} 3+\mathrm{C} 22: 5+\mathrm{C} 22: 6 ; \mathrm{C} 20: 5$ was not detected

$\mathrm{n} 6=\mathrm{C} 18: 2+\mathrm{C} 18: 3 \mathrm{n} 6+\mathrm{C} 20: 4+\mathrm{C} 22: 4+\mathrm{C} 20: 3+\mathrm{C} 20: 2$

FAME are the fatty acid methyl esters 
to $\mathrm{n} 3$ may be impaired. Furthermore, increases in intramuscular PUFA concentration pose greater potential for lipid peroxidation (Kouba and Mourot, 2011). Higher TBARS values in $5 \mathrm{~d}$-refrigerated thigh meat because of broiler diets with DDGS concentrations higher than 12\% were described (Schilling et al., 2010). Thus, future feeding trials should concentrate on increasing antioxidative capacity in meat, for example, with adapted tocopherol concentrations in diets, when increasing DDGS content. In general, it has to be stated that changes in dietary oil source may have a major impact on the fatty acid profile.

\section{Conclusion}

In conclusion, the study could show that increasing DDGS contents up to $24 \%$ in broiler diets did not impair performance. A precondition, however, is a sufficient supply with nutrients to cover requirements. Supplementation of NSP-hydrolyzing enzymes improved ADG and FCR in grower and finisher phases. $\mathrm{AME}_{\mathrm{N}}$ and $\mathrm{DM}$ digestibility as well as $\mathrm{N}$ retention were neither influenced by DDGS content nor enzyme supplementation. Hence, it seems that the improved FCR affected by enzyme supplementation is due to intermediate metabolism processes. The substitution of soybean meal and corn with DDGS and vegetable oil only had minor effects on the sensory quality of broiler breast meat, with increased tenderness in high DDGS diets $(p<0.1)$. The intramuscular amount of PUFAs (especially $\mathrm{n} 6$ family) was increased with increasing inclusion rate of DDGS and vegetable oil, as well as with the addition of NSP-hydrolyzing enzyme.

\section{References}

Altmann, F. (1992): Determination of amino sugars and amino acids in glycoconjugates using precolumn derivatization with o-phthalaldehyde. Analytical Biochemistry 204, 215-219.

Cortinas, L., Villaverde, C., Galobart, J., Baucells, M.D., Codony, R. and A.C. Barroeta (2004): Fatty acid content in chicken thigh and breast as affected by dietary polyunsaturation level. Poultry Science 83, 1155-1164. Corzo, A., Schilling, M.W., Loar II, R.E., Jackson, V., Kin, S. and V. Radhakrishnan (2009): The effects of feeding distillers dried grains with solubles on broiler meat quality. Poultry Science 88, 432-439.
Crespo, N. and E. Esteve-Garcia (2002): Nutrient and fatty acid depositon in broilers fed different dietary fatty acid profiles. Poultry Science 81, 1533-1542.

De Smet, S., Raes, K. and D. Demeyer (2004): Meat fatty acid composition as affected by fatness and genetic factors: A review. Animal Research 53, 81-98.

Emiola, I.A., Opapeju, F.O., Slominski, B.A. and C.M. Nyachoti (2009): Growth performance and nutrient digestibility in pigs fed wheat distillers dried grains with solubles-based diets supplemented with a multicarbohydrase enzyme. Journal of Animal Science 87, 2315-2322.

Fernandez, X., Monin, G., Talmant, A., Mourot, J. and B. Lebret (1999): Influence of intramuscular fat content on the quality of pig meat - 1 . Composition of the lipid fraction and sensory characteristics of $m$. longissimus lumborum. Meat Science 53, 59-65.

GfE (1999): Empfehlungen zur Energie- und Nährstoffversorgung der Legehennen und Masthühner (Broiler) / Ausschuss für Bedarfsnormen der Gesellschaft für Ernährungsphysiologie. DLG-Verlags-GmbH, Frankfurt/ Main, 185 pp.

González-Alvarado, J.M., Jiménez-Moreno, E., GonzálezSánchez, D., Lázaro, R. and G.G. Mateos (2010): Effect of inclusion of oat hulls and sugar beet pulp in the diet on productive performance and digestive traits of broilers from 1 to 42 days of age. Animal Feed Science and Technology 162, 37-46.

González-Alvarado, J.M., Jiménez-Moreno, E., Valencia, D.G., Lázaro, R. and G.G. Mateos (2008): Effects of fiber source and heat processing of the cereal on the development and $\mathrm{pH}$ of the gastrointestinal tract of broilers fed diets based on corn or rice. Poultry Science 87, 1779-1795.

Gracia, M.I., Lázaro, R., Latorre, M.A., Medel, P., Araníbar, M.J., Jiménez-Moreno, E. and G.G. Mateos (2009): Influence of enzyme supplementation of diets and cooking-flaking of maize on digestive traits and growth performance of broilers from 1 to 21 days of age. Animal Feed Science and Technology 150, 303-315.

Hansen, I., Knudsen, K.E. and B.O. Eggum (1992): Gastrointestinal implications in the rat of wheat bran, oat bran and pea fibre. British Journal of Nutrition 68, 451-462.

Heincinger, M., Balogh, K., Mézes, M. and H. Fébel (2012): Effects of distillers dried grain with soluble (DDGS) on meat quality, lipid peroxide and some of antioxidant status parameters of fattening Turkey. Journal of Poultry Science 49, 268-272. 
Hill, F.W. and D.L. Anderson (1958): Comparison of metabolizable energy and productive energy determinations with growing chicks. Journal of Nutrition 64, 587-603.

Hogberg, A. and J.E. Lindberg (2004a): Influence of cereal non-starch polysaccharides and enzyme supplementation on digestion site and gut environment in weaned piglets. Animal Feed Science and Technology 116, 113128.

Hogberg, A. and J.E. Lindberg (2004b): Influence of cereal non-starch polysaccharides on digestion site and gut environment in growing pigs. Livestock Production Science $87,121-130$.

Honda, K., Kamisoyama, H., Kubo, S., Motoori, T. and S. Hasegawa (2010): Effects of dietary fat levels on amino acid digestibility at different sites of chicken intestines. Journal Poultry Science 47, 227-235.

Hulan, H.W., Ackman, R.G., Ratnayake, W.M.N. and F.G. Proudfoot (1988): Omega-3 fatty-acid levels and performance of broiler-chickens red redfish meal or redfish oil. Canadian Journal of Animal Science 68, 533-547.

Jagger, S., Wiseman, J., Cole, D.J.A. and J. Craigon (1992): Evaluation of inert markers for the determination of ileal and fecal apparent digestibility values in the pig. British Journal of Nutrition 68, 729-739.

Jiménez-Moreno, E., Gonzáles-Serrano, A., Lázaro, R. and G.G. Mateos (2009): Effect of dietary fiber and fat on performance and digestive traits of broilers from one to twenty-one days af age. Poultry Science 88, 2562-2574.

Ketels, E. and G. DeGrote, G. (1989): Effect of ratio of unsaturated to saturated fatty acids of the dietary lipid fraction on utilization and metablizable energy of added fats in young chicks. Poultry Science 68, 1506-1512.

Kluth, H. and M. Rodehutscord (2010): Effect of the duration of prefeeding on amino acid digestibility of wheat distillers dried grains with solubles in broiler chicken. Poultry Science 89, 681-687.

Kouba, M. and J. Mourot (2011): A review of nutritional effects on fat composition of animal products with special emphasis on n-3 polyunsaturated fatty acids. Biochimie 93, 13-17.

Lan, Y., Opapeju, F.O. and C.M. Nyachoti (2008): True ileal protein and amino acid digestibilities in wheat dried distillers' grains with solubles fed to finishing pigs. Animal Feed Science and Technology 140, 155-163.

Leytem, A.B., Kwanyuen, P. and P.A. Thacker (2008): Nutrient excretion, phosphorus characterization, and phos- phorus solubility in excreta from broiler chicks fed diets containing graded levels of wheat distillers grains with solubles. Poultry Science 87, 2505-2511.

Lopez-Ferrer, S., Baucells, M.D., Barroeta, A.C. and M.A. Grashorn (2001): n-3 enrichment of chicken meat. 1. Use of very long-chain fatty acids in chicken diets and their influence on meat quality: fish oil. Poultry Science 80, 741-752.

Lumpkins, B.S., Batal, A.B. and N.M. Dale (2004): Evaluation of distillers dried grains with solubles as a feed ingredient for broilers. Poultry Science 83, 1891-1896.

Montagne, L., Pluske, J.R. and D.J. Hampson (2003): A review of interactions between dietary fibre and the intestinal mucosa, and their consequences on digestive health in young non-ruminant animals. Animal Feed Science and Technology 108, 95-117.

Naumann, C. and R. Bassler (2012): Die chemische Untersuchung von Futtermittel. VDLUFA-Verlag, Darmstadt, Germany.

Nyachoti, C.M., House, J.D., Slominski, B.A. and I.R. Seddon (2005): Energy and nutrient digestibilities in wheat dried distillers' grains with solubles fed to growing pigs. Journal of the Science of Food and Agriculture 85, 2581-2586.

Oryschak, M., Korver, D., Zuidhof, M. and E. Beltranena (2010): Nutritive value of single-screw extruded and nonextruded triticale distillers dried grains with solubles, with and without an enzyme comples for broilers. Poultry Science 89, 1411-1423.

Owusu-Asiedu, A., Simmins, P.H., Brufau, J., Lizardo, R. and A. Péron (2010): Effect of xylanase and betaglucanase on growth performance and nutrient digestibility in piglets fed wheat-barley-based diets. Livestock Science 134, 76-78.

Ratnayake, W.M.N., Ackman, R.G. and H.W. Hulan (1989): Effect of redfish meal enriched diets on the taste and n-3 pufa of 42-day-old broiler chickens. Journal of the Science of Food and Agriculture 49, 59-74.

Schedle, K. (2016): Sustainable pig and poultry nutrition by improvement of nutrient utilisation - A review. Die Bodenkultur: Journal of Land Management, Food and Environment 67, 45-60.

Schedle, K., Mair, C., Leitgeb, R. and W. Windisch (2010a): Zootechnical performance and carcass characteristics of broiler chicks fed different kindsand concentrations of distillers dried grains with solubles (DDGS). Die Bodenkultur: Journal of Land Management, Food and Environment 61, 37-48. 
Schedle, K., Mair, C. and W. Windisch (2010b): Effects of feeding wheat distillers dried grains with solubles (DDGS), on performance, carcass quality, colon digesta dry matter and ammonia, as well as plasma urea in pigs for fattening. Züchtungskunde 82, 303-315.

Schilling, M.W., Battula, V., Loar II, R.E., Jackson, V., Kin, S. and A. Corzo (2010): Dietary inclusion level effects of distillers dried grains with solubles on broiler meat quality. Poultry Science 89, 752-760.

Slominsky, B.A. (2011): Recent advances in research on enzymes for poultry diets. Poultry Science 90, 2013-2023.

Sukhija, P.S. and D.L. Palmquist (1988): Rapid method for determination of total fatty acid content and composition of feedstuffs and feces. Journal of Agricultural and Food Chemistry 36, 1202-1206.

Thacker, P.A. and G.P. Widyaratne (2007): Nutritional value of diets containing graded levels of wheat distillers grains with solubles fed to broiler chicks. Journal of the Science of Food and Agriculture 87, 1386-1390.

Whitney, M.H. and G.C. Shurson (2004): Growth performance of nursery pigs fed diets containing increasing levels of corn distiller's dried grains with solubles originating from a modern Midwestern ethanol plant. Journal of Animal Science 82, 122-128.

Widmer, M.R., McGinnis, L.M., Wulf, D.M. and H.H. Stein (2008): Effects of feeding distillers dried grains with solubles, high-protein distillers dried grains, and corn germ to growing-finishing pigs on pig performance, carcass quality, and the palatability of pork. Journal of Animal Science 86, 1819-1831.

Widyaratne, G.P. and R.T. Zijlstra (2007): Nutritional value of wheat and corn distiller's dried grain with solubles: Digestibility and digestible contents of energy, amino acids and phosphorus, nutrient excretion and growth performance of grower-finisher pigs. Canadian Journal of Animal Science 87, 103-114.

Wood, J.D., Richardson, R.I., Nute, G.R., Fisher, A.V., Campo, M.M., Kasapidou, E., Sheard, P.R. and M. Enser (2003): Effects of fatty acids on meat quality: a review. Meat Science 66, 21-32.

Woyengo, T.A. and C.M. Nyachoti (2011): Supplementation of phytase and carbohydrases to diets for poultry Canadian Journal of Animal Science 91, 177-192.

Yin, Y.L., McEvoy, J.D.G., Schulze, H., Hennig, U., Souffrant, W.B. and K.J. McCracken (2000): Apparent digestibility (ileal and overall) of nutrients and endogenous nitrogen losses in growing pigs fed wheat (var. Soissons) or its by-products without or with xylanase supplementation. Livestock Production Science 62, 119-132.

Zijlstra, R.T., Owusu-Asiedu, A. and P.H. Simmins (2010): Future of NSP-degrading enzymes to improve nutrient utilization of co-products and gut health in pigs. Livestock Science 134, 255-257. 